\title{
The Enlightenment of DBAE Theory and the Study of China's Art Education Theory
}

\author{
Zhang Xuemei \\ ${ }^{1}$ Southwest Minzu University, Chengdu, Sichuan 610041China \\ ${ }^{2}$ Aba Teachers University, Aba, Sichuan 623002 China \\ snowzxm123@163.com
}

Keywords: Art education theory, DBAE art education thought, Art education reform

\begin{abstract}
To enrich the relevant research theories of Eisner DBAE art education thought and its enlightenment and reference to the reform of basic art education in China, and to promote the development of China's art education theory, firstly, the related theoretical concepts related to DBAE art education thoughts are expounded. Then the problems existing in the current stage of China's art education theory are analyzed, and on this basis, the enlightenment of DBAE on the development of China's art education is proposed. Finally, relevant opinions and measures are put forward, hoping to provide some reference for the development of China's art education reform.
\end{abstract}

\section{Introducation}

Art education has an irreplaceable and unique role in the entire education system. DBAE is an art education theory that has evolved over 20 years of development. The introduction of DBAE art education thoughts into China has caused discussion and research by Chinese art educators. However, at present, it only introduces the educational philosophy, educational goals and characteristics of the idea, without fully and systematically elaborating the DBAE art education theory. For many front-line art teachers in China, they don't fully understand DBAE art education thoughts, and they don't know the essence of this theory. As a result, DBAE art education theory has not been widely popularized in the actual teaching process in China. What are the disadvantages and advantages of DBAE art education theory? Whether it can really adapt to the current situation of art education in China, these issues deserve further consideration. Therefore, it is necessary to conduct a comprehensive and in-depth study of DBAE art education theory, which has certain enlightenment and guidance for the reform of basic art education in China and enriches the research of art education theory in China.

\section{Literature review}

DBAE is an art education theory that has evolved over 20 years of development. DBAE's full name is Discipline-Based Art Education, literally translated as "subject-centered art education". After years of development, it is now called "a comprehensive art education", which belongs to an art education model (Bao et al., 2015). DBAE is a comprehensive art education concept and 
learning method that aims to use art as a formal course in general education, emphasizing the ability to develop students' creation, reading and commenting (Bevan \& Werhane, 2015). Art can provide a sense of sight to human beings. Now it has become visual art to express the most beautiful things people can see. It makes illusory things understandable, which is impossible for other disciplines; art can help people criticize society and convey a certain value in a metaphorical way (Colie, 2015). The art curriculum is essentially a programmatic and selective way for students to participate in activities, which is very educational (Dekker, 2015). In 1906, Li Ruiqing asked for permission to set up Liangjiang Excellent Normal School in Nanjing, which became the earliest higher normal art education department in China (John, 2015). In 1922, the National Beijing Fine Arts School was established to offer Western art classes for students of Chinese painting and offer Chinese painting courses for students of Western painting. Foreign languages and ethics are compulsory for students of both majors (Paganelli, 2015). In 1928, a group of intellectual youths who returned from France began to participate in art education. The most representative ones were Lin Fengmian and $\mathrm{Xu}$ Beihong (Pawson, 2015). The new curriculum standards promulgated in China in 2011 define the art discipline as a humanities discipline and divide the art discipline content into four areas of study: "Shaping and Expression”, "Design and Application”, “Appreciation and Review" and "Integration and Exploration" (Sun et al., 2016). Eisner divides the curriculum into three categories: social centers, children's centers, and subject centers (Wren, 2014). Eisner believes that the art curriculum should involve three aspects: art creation - to cultivate students' artistic creativity and artistic expression; art criticism - to cultivate students' ability to accept and feel aesthetics; art culture - to train students to understand the art in the cultural context with a historical perspective (Zhang et al. 2015).

\section{Methodology}

\subsection{The overview of DBAE art education thoughts}

DBAE is a theory of art education (full name: Discipline-Based Art Education), which is translated into "Discipline-Based Art Education" in China, and it is now called "a comprehensive art education". It is an art education model. It not only refers to the learning of art, but also the combination of art and other disciplines-mathematics, history, geography, etc.-is a comprehensive art education theory based on disciplines. Based on the purpose of art education, teaching evaluation and teaching resources, DBAE theory has established a perfect theoretical system based on four disciplines, reflecting the characteristics of comprehensive, balanced, and continuing education of art education, as shown in Figure 1.

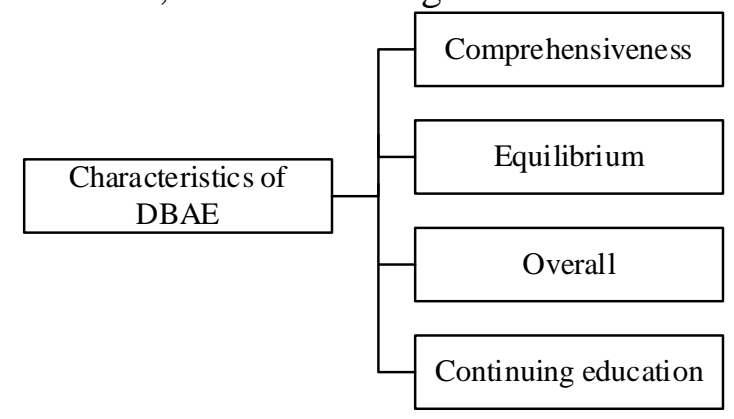

Figure 1. Characteristics of DBAE

The four areas of DBAE are mainly shown in Figure 2: 


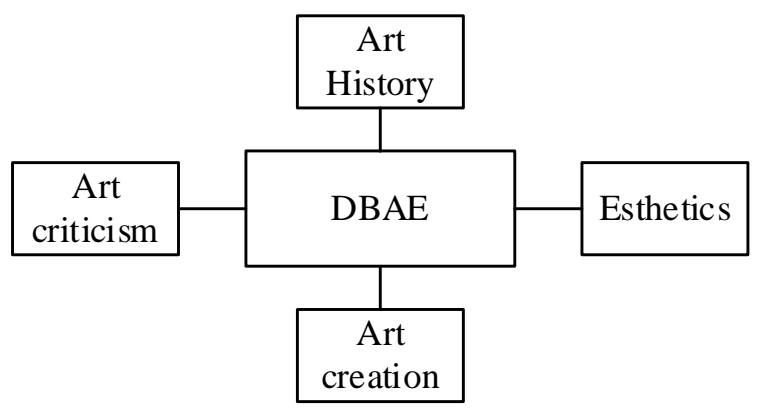

Figure 2. Four areas of DBAE Division

The four areas of DBAE enable people to learn art from a novel perspective. The main teaching contents are as follows:

First, art creation. That is, making art works, using materials, tools and techniques in the production process to explore the artistic imagination of students. The art creation in the classroom requires the direct participation of the students, and the students need to inject their own thoughts, emotions and imaginations in the creative process. In the process of art creation, students can perceive the beauty of art, enhance their ability to appreciate, enhance their self-confidence, and increase their interest in learning.

Second, art criticism. Through in-depth understanding of artistic works, it inspires students' critical thinking and clarifies the status and role of art in society. Art criticism is a sublimation of the appreciation of art works. Its purpose is to increase people's appreciation and understanding of art and to understand the role of art in society. The most basic issues discussed in art criticism are the content, meaning, value of the work and the nature of the art.

Third, art history. It records important events and historical experiences in the development of human civilization. It not only helps people understand the changes in artistic style, but also helps people deepen their understanding of complex artistic practice activities.

Fourth, aesthetics. The aesthetics in the narrow sense is art philosophy. It focuses on the nature, meaning and value of art. Through the discussion of these issues, students can clearly judge the art phenomenon and form the standard to criticize art works.

DBAE's teaching objectives in four subject areas include:

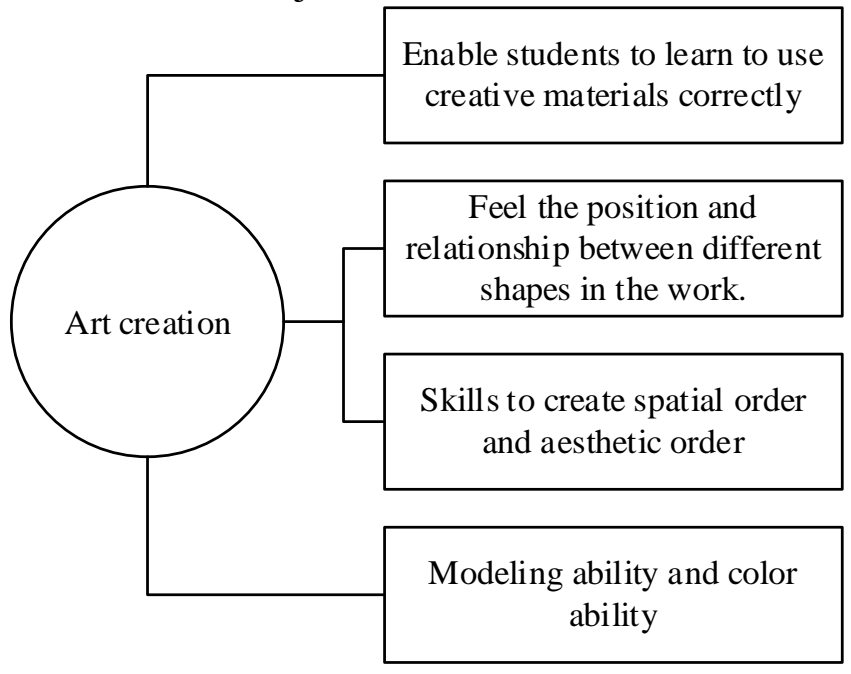

Figure 3. Teaching objectives of artistic creation 


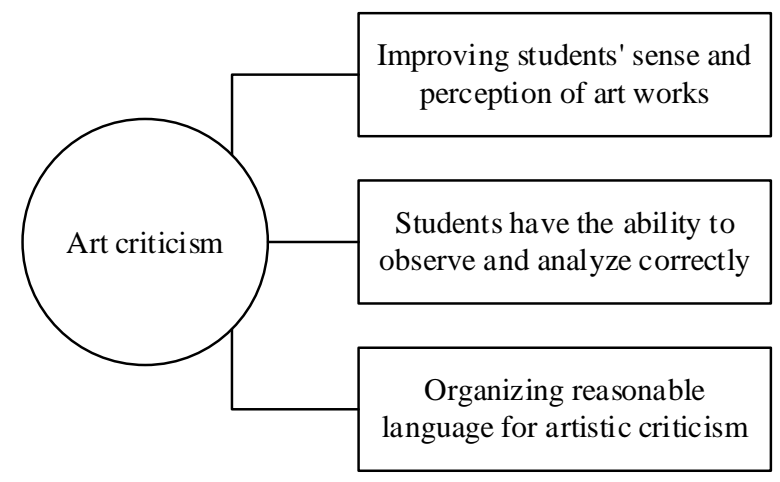

Figure 4. Teaching objectives of art criticism

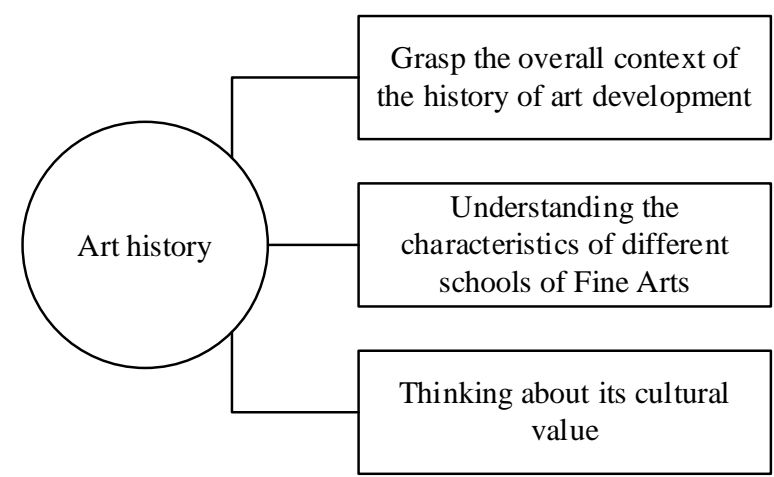

Figure 5. Teaching objectives of art history

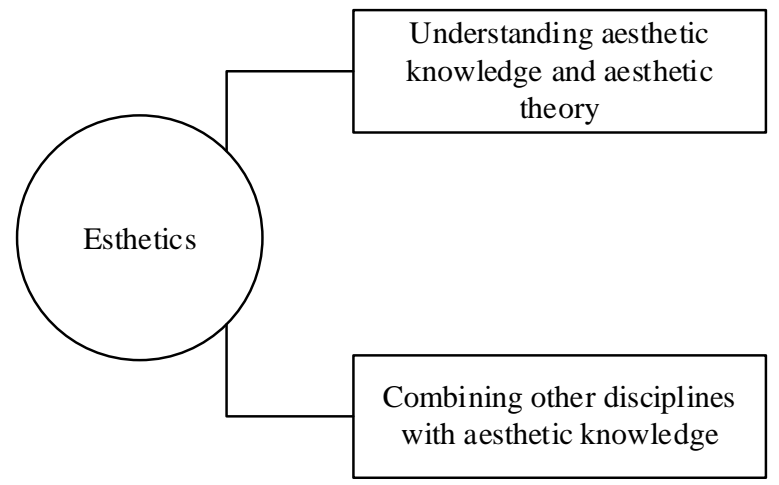

Figure 6. Teaching objectives of aesthetics

Figure 3 is the teaching goal in art creation. First, to enable students to learn to use creative materials correctly; second, to make students feel the position and relationship between the works; third, to enable students to have the skills to create spatial order and aesthetic order; fourth, to enable students to have the ability to shape and color, and their works are expressive.

Figure 4 is the teaching goal in art criticism. First, improve students' feelings and perceptions of art works; second, to enable students to have the ability to observe and analyze correctly; third, to enable students to organize a reasonable language for artistic criticism and to express their opinions or feelings.

Figure 5 is the teaching goal in the history of art. First, grasp the overall context of the history of art development; second, understand the different artistic characteristics of different art schools; third, understand art works and think about their cultural values based on the historical background.

Figure 6 is the teaching goal in aesthetics. First, understand aesthetic knowledge and aesthetic theory, and cultivate aesthetic ability; second, in the process of appreciation or creation, combined 
with other disciplines to apply aesthetic knowledge.

\subsection{The general situation and existing problems of Chinese art education}

In the more than half a century since the founding of New China, China has carried out many reforms on basic art education. Coupled with the continuous efforts of many art educators and the insistence on the original intention of art education, basic education has achieved certain results. The development of basic art education in China can be roughly divided into three stages:

The first phase was from the early days of the founding of New China to the end of the 1970s. During this period, due to the instability of the political environment, the social environment was unstable, and the entire education sector was affected. Art education was no exception. In 1963, The "New Teaching Plan for Full-time Primary and Secondary Schools (Draft)" issued by the Ministry of Education requires that primary and secondary schools must have at least one art class per week, which is a powerful guarantee for the continuity of art education.

The second stage was from the late 1970s to the beginning of the 21st century. After the Cultural Revolution, the social environment has become more stable. During this period, the social forms of all aspects of our country have undergone rapid changes. The requirements of the comprehensive implementation of quality education issued by the state have made art education more important than ever. In 1978, the state officially renamed the "drawing class" as "art class", and the term art class has been used since then. In addition, the scope of art education at this stage has been expanded, and the categories have also been enriched. It is no longer limited to the art education of the school. There are many art education and training institutions in the society, which provides a broader environment for the development of art education.

The third stage is from the beginning of the 21st century to the present. At the beginning of the new century, China launched a new round of basic education reform for the new century. In 2001, the Ministry of Education issued the "Basic Education Reform Outline", which called for the full implementation of the party's education policy and the implementation of quality education. Due to the advancement of quality education, the status of art education in basic education has been improved unprecedentedly, and the value and role of art education has been widely recognized. This period is a flourishing period of concentrated development of basic art education in China. There are many factors that will affect the development of basic art education. One of them is to cultivate new types of art teachers. In terms of teachers, the state attaches great importance to the cultivation of teachers and has set up many art colleges and universities to cultivate professional talents of art education.

The problems in the art education curriculum in China mainly include the following aspects:

First, as our primary and middle schools attach too much importance to exam-oriented education and the requirement of enrollment rate, the ordinary full-time primary and middle schools in some regions of China (especially remote areas) often don't pay much attention to art education. They don't regard art class as important as other subjects, but just regard it as a general skill course to learn. In addition, the curriculum structure of art teaching is relatively simple, and most of the textbooks' content is mainly for art appreciation, and there are few courses or activities related to art practice. In this way, students will feel more monotonous and less interesting when they study. It is easy to cause students to be weak in practical ability and innovation ability.

Second, neglecting the integration of art disciplines and other disciplines, the teaching model of interdisciplinary teaching is rarely implemented. Influenced by the traditional model, it emphasizes the subject-centered and teacher-centered teaching in practical teaching. The students mainly acquire knowledge through the way of teacher's words and deeds, which limits the individual's personality development. 
Third, in the actual teaching of teachers, most art teachers use the way of stylized "teaching materials" instead of "using textbooks". Most art teachers teach students in a step-by-step manner in accordance with national textbooks. They only focus on the transfer of skills and basic knowledge, lack of communication between art courses and other courses, and they can't connect the art courses with local, social, and historical cultures. In this way, students will lose interest in the art curriculum, and students' enthusiasm for learning will be difficult to mobilize.

Generally speaking, the art education of our country is advancing in the twists and turns. From the original single content, the discrete disciplines to the partial integration of the subject content, it reflects the development trend of harmonious integration, from scientific rationalism to humanistic romanticism. Rationality and romance have their own advantages and disadvantages. The most crucial thing is that when foreign educational ideas continue to infiltrate our cultural system and education system, the Chinese can always keep a clear judgment, keep advance and retreat in a timely manner, and take advantage of the two, explore the educational ideas suitable for Chinese art pedagogical education, and walk out of the path of our unique Chinese art curriculum education.

\subsection{The enlightenment of DBAE art education thought on the development of art education in China}

First, the enlightenment on the synthesis of disciplines. As a discipline, art and other disciplines always have inevitable or accidental connections. From this aspect, it is very meaningful to study the relationship between art disciplines and other disciplines and to realize the integration of art and various disciplines. DBAE art education theory is an educational concept that pays great attention to the integration of art and other disciplines. First of all, the integration of art courses and other historical and cultural courses can integrate art with literature, sociology, history and other humanities, so that students can learn art knowledge and understand some historical and cultural knowledge at the same time; secondly, the combination of art class and other subjects can also detect students' mastery of knowledge of other subjects and enhance students' consolidation of knowledge; thirdly, it puts forward a higher level of standards for teachers' ability and requires art teachers to have more extensive knowledge. This also stimulates teachers' thirst for knowledge and encourages teachers to constantly improve themselves. In view of the problems exposed by DBAE in the actual teaching activities in the United States, it should be taken as a warning. Therefore, in the interdisciplinary comprehensive teaching of Chinese art education, it is necessary to master the comprehensive degree and distinguish the priorities. The teaching of art courses should be centered on the art discipline and combined with other disciplines.

Second, the enlightenment on the curriculum standards. When DBAE art education thought entered China, it had a great impact on the art education field in China. From the "Compulsory Education Art Curriculum Standards (2011 Edition)" formulated by China, it can be concluded that the new curriculum standard summarizes the art curriculum from four aspects and requires teaching according to the physical and mental development characteristics of students of different ages. Don't deliberately strengthen the training of professional skills, but regard art as a humanities subject. It is a kind of cultural study, which abandons the utilitarian pursuit of art courses. This is the reference to Eisner DBAE art thoughts. The new curriculum standard clearly states that art courses must pursue humanity, and art classes should be taught as a humanities discipline. Through the study of art courses, students can understand the profoundness of Chinese traditional culture and absorb the essence of traditional culture. In addition, the new curriculum standards require the analysis of artworks from multiple perspectives, encouraging students to learn to explore various aspects of art in a variety of ways, and to clarify the overall clues to the development of art, and even try to require students to use art criticism to make a higher level analysis of the background, 
form, and emotional expression of artworks. Students are required to understand the daily research work of artists, critics, art historians and aestheticians. These aspects are also in line with the four subject areas advocated by DBAE.

Third, the enlightenment on art teachers. DBAE art education theory believes that art should be studied as a cultural course rather than a skill course. Therefore, in the actual teaching process, art teachers should change the practice of focusing only on skills learning and should strengthen the teaching of cultural knowledge in art disciplines. Teachers should boldly break the discipline-based and textbook-centered stereotypes, use a variety of teaching resources to expand the content space of art courses, strengthen the connection between art classes and other cultural courses, and strengthen the connection between student experience and teaching content. In addition, teachers should strengthen the reform of teaching methods and achieve high efficiency and high quality of art teaching. In the face of the opportunity of the new curriculum reform, it is necessary to build a scientific disciplinary system suitable for students of different ages. Art teachers should develop corresponding teaching plans according to the psychological development characteristics of students of different ages. DBAE art education theory also emphasizes interdisciplinary learning and the integration of art and other disciplines. This requires art teachers themselves to have extensive scientific and cultural knowledge. In art teaching, it is not only the study of theoretical knowledge and art techniques, but also involves some humanistic knowledge, natural science knowledge and historical knowledge. Finally, art teachers should also pay attention to the cultivation of friendly relations between teachers and students and strengthen interaction and exchanges with students.

\section{Results}

Eisner's DBAE art education ideas are strongly supported by the Getty Art Center and affect art education in many regions and countries. China has also sent a number of visiting scholars to participate in the training course of DBAE theory. With the development of the times and the mutual penetration of multiculturalism, international exchanges can broaden the horizons of Chinese art educators and timely grasp the new trends of foreign art education reform. Learning from the advanced experience of foreign education reform can avoid the detour of education reform in China. The perfection of DBAE art education thought should be taken as the reference experience in the current art education reform in China. It puts forward the following suggestions for the specific situation and existing problems of China's art education:

\subsection{Re-establish the status of art education}

The intrinsic value of art education and the spiritual influence on human beings are still irreplaceable by other activities. To sum up Professor Eisner's three major contributions to art education, the first is his emphasis on the value theory of art education. From the traditional aesthetic education thoughts in our country, it can also conclude that art is not only the educational tool with artistic and social functions, but the artistic realm is the spiritual realm of realizing ideal personality, and it has its own value that can't be ignored. Whether it is the Western art education theory or the traditional Chinese aesthetic education thought, it can be concluded that only art education can achieve the integrated development of the human spirit. Therefore, while school education emphasizes the study of other subjects, the status and quality of art education can't be ignored. 


\subsection{Develop art education theory suitable for national conditions}

China's art education theory should be developed in combination with China's historical and cultural background, traditional aesthetic concepts, and students' physical and mental rules. Some Western art education theories and educational viewpoints should be appropriately selected for reference. It is preliminarily proposed that the curriculum of aesthetic education should include courses such as art history, art creation, art criticism, art culture, and art education history. It consists of education courses with human history and aesthetics. Under the circumstance that the basic discipline structure art + pedagogy remains unchanged, there are some adjustments to the contents of general education courses and professional basic courses: general education classes, reducing the proportion of ideological and political courses, and adding classes to cultivate humanistic spirit and natural sciences. For example, it includes reading classic cultural works, reading, writing, music, etc. to develop students' comprehensive literacy and cultivate students' multiple abilities. At the same time, in the elective course of the art professional class, local culture can be introduced into the classroom. Not only the local precious folk traditional culture and art can be understood by young people, but also traditional folk culture and art are passed down in another form.

\subsection{Establish an art curriculum that aims to achieve educational goals}

To achieve the purpose of art education, it is necessary to establish a concrete and feasible curriculum structure, and the curriculum structure should be as unified as possible and avoid fragmentation. The curriculum structure should be adjusted accordingly according to the teaching objectives. It is also possible to combine modern art education with traditional Chinese culture to develop new art courses. The specific measures are to organize the experience class of folk art, which is carried out in the form of lectures, practical topic reports, exchanges between China and Taiwan, participation in international education conferences or art exhibitions. It not only cultivates the students' international vision, but also makes the educational learning results interesting, local, practical and effective.

\subsection{Optimize the teaching staff and strengthen the "demonstration" teaching method}

In art criticism, art appreciation, folk art, and some art courses that require more professional guidance, it is recommended that professional teachers with experience in the class can teach. Because these experienced teachers clearly know how to teach with the most effective teaching methods in a limited class time. In this process, the students will be subtly influenced by the teacher's teaching literacy, thus enhancing their personality charm. At the same time, teachers can take more proportion in the use of teaching language and teaching methods, and they can also pay attention to the training of students' learning quality and ability by combining with the characteristics of art majors.

\section{Conclusion}

Under the influence of the era of diversification and informationization, the development of science and technology is further accelerated, and education requires international exchanges. DBAE art education thought not only pays attention to the balanced integration of knowledge in four fields, but also has its unique characteristics in constructing the curriculum system. With the increasing social and cultural exchanges in contemporary times, it is necessary to continuously learn advanced foreign teaching ideas. Based on the educational situation in China, combined with 
excellent guiding ideology, it is necessary to construct a new art education curriculum system suitable for China's development. It systematically studies and interprets DBAE theory from the aspects of its concept, characteristics, teaching content and teaching objectives. Combined with the current situation and existing problems of art education in China, the theory is analyzed for the enlightenment of art education in China. DBAE art education theory is not a completely correct truth, and it may not be all suitable for China's art education. It should learn from its strengths to develop art education with Chinese characteristics.

\section{References}

[1] Bao-Qing, L. I., Chun-Xia, L. I., \& University, S. (2015). Bell hooks' critical curriculum theory and its enlightenments. Journal of Higher Education.

[2] Bevan, D., \& Werhane, P. (2015). The inexorable sociality of commerce: the individual and others in adam smith. Journal of Business Ethics, 127(2), 327-335.

[3] Colie, R. L. (2015). Opposition to louis xiv. the political and social origins of the french enlightenment, by lionel rothkrug. Journal of Modern History, 71(1), 73-74.

[4] Dekker, E. (2015). Two approaches to study the value of art and culture, and the emergence of a third. Journal of Cultural Economics, 39(4), 309-326.

[5] John, S. (2015). Inductive risk and the contexts of communication. Synthese, 192(1), 79-96.

[6]Paganelli, M. P. (2015). Recent engagements with adam smith and the scottish enlightenment. History of Political Economy, 47(3), 363.

[7] Pawson, E. (2015). What sort of geographical education for the anthropocene. Geographical Research, 53(3), 306312.

[8] Sun, G., Tian, Y., \& Wang, X. (2016). Essential characteristics and enlightenments on how the european medieval universities to be classic. Review of Higher Education.

[9] Wren, B. (2014). Thinking postmodern and practising in the enlightenment: managing uncertainty in the treatment of children and adolescents. Feminism \& Psychology, 24(2), 271-291.

[10] Zhang, Z., Hinger, J., Audretsch, D. B., \& Song, G. (2015). Environmental technology transfer and emission standards for industry in china. Journal of Technology Transfer, 40(5), 743-759. 